\title{
ROSS RIVER VIRUS INFECTION
}

\section{WHAT IS ROSS RIVER VIRUS?}

- Ross River virus is a germ that infects people, particularly in rural areas, sometimes causing a flulike illness with joint pains.

- Ross River virus is not fatal.

\section{HOW IS ROSS RIVER VIRUS SPREAD?}

- The virus is spread by certain types of female mosquitoes.

- Female mosquitoes feed on animals and people. If they feed on the blood of an infected animal, the mosquito may become infected. The virus then multiplies within the mosquito and is passed to other animals or people when the mosquito feeds again.

- Infections tend to peak in the summer and autumn months.

- The virus is not spread directly from one person to another.

\section{WHAT ARE THE SYMPTOMS OF ROSS RIVER VIRUS INFECTION?}

- Many people who are infected with the virus will never develop symptoms.

- Some people will have flu-like symptoms that include fever, chills, headache and aches and pains in the muscles and joints.

- Some joints can become swollen, and joint stiffness may be particularly noticeable in the morning.

- Sometimes a rash occurs on the body, arms or legs. The rash usually disappears after seven to 10 days.

- A general feeling of being unwell, tired or weak may also occur at times during the illness. This may affect work performance.

\section{HOW SOON DO SYMPTOMS DEVELOP AFTER BEING BITTEN BY AN INFECTED MOSQUITO?}

- Symptoms usually show between seven to nine days after being bitten by an infected mosquito. This interval can vary but is generally between five to 21 days.

\section{HOW LONG DOES THE ILLNESS LAST?}

- Many people will recover completely within a few weeks. Others have symptoms lasting more than three months, and in rare cases for more than a year.

- The symptoms can re-occur on and off over this period of time. Usually the symptoms become less severe each time they recur.

- A full recovery can be expected.

\section{WHAT IS THE TREATMENT FOR ROSS RIVER VIRUS INFECTION?}

- There is no specific treatment for Ross River virus infection.

- Your doctor will be able to advise you on medications that will help ease the discomfort of the symptoms.

- Plenty of rest, along with moderate exercise and healthy eating, may help in your recovery.

\section{HOW DO I KNOW IF I HAVE ROSS RIVER VIRUS INFECTION?}

- If you have symptoms, see your doctor, who can order a blood test to diagnose Ross River virus infection.

\section{CAN ROSS RIVER VIRUS DISEASE BE PREVENTED?}

- Yes! Avoid being bitten by mosquitoes, especially in the summer and autumn months when infections peak.

- Various species of mosquitoes bite at different times. Avoid being outside in the late afternoon and dusk. Mosquitoes are usually most active up to one to three hours after sunset and again around dawn.

- When outside wear loose fitting, light coloured clothing that covers your arms and legs, and use an insect repellent that contains the chemical diethyl toluamide (DEET).

- Fit fly screens to all windows, doors and chimneys and keep them in good repair.

- Use a knockdown insecticide in bedrooms half an hour before going to bed. Use insecticides according to instructions. 战

For more information please contact your local public health unit, local government, community health centre, pharmacist, doctor or www.arbovirus.health.nsw.gov.au 